\title{
Characterization of Calcium Aluminate Cement Phases when in Contact with Simulated Body Fluid
}

\author{
Ivone Regina de Oliveira ${ }^{a *}$, Talita Luana de Andrade ${ }^{a}$, Renata Martins Parreira ${ }^{a}$, \\ Marcos Jacobovitz, Victor Carlos Pandolfelli \\ ${ }^{a}$ Instituto de Pesquisa e Desenvolvimento - IP\&D, Universidade do Vale do Paraiba - Univap, \\ Av. Shishima Hifumi, 2911, São José dos Campos, SP, Brazil \\ ${ }^{b}$ Consultório Dr. Marcos Jacobovitz, Rua Maestro João Sepe, 900, sala 164, \\ Edifício Medical Center- Jardim Paraiso, São Carlos, SP, Brazil \\ 'Departamento de Engenharia de Materiais - Dema, Universidade Federal de São Carlos - UFSCar, \\ Rod. Washington Luiz, Km 235, São Carlos, SP, Brazil
}

Received: October 6, 2014; Revised: March 25, 2015

\begin{abstract}
Recent studies involving the use of calcium aluminate cement (CAC) as a biomaterial are based on commercial products. Improvements can be attained by investigating the properties of their crystalline phases in order to better design the material's composition. Therefore, calcium aluminate phase samples immersed in simulated body fluid (SBF) solutions prepared according to Kokubo's (KSBF) and Rigo's (RSBF) methodology had their pH evaluated. The surfaces of these samples were analyzed by SEM, EDX and XRD techniques. The treatment with KSBF did not favor the precipitation of calcium phosphate phases on the surface of CAC phases. On the other hand, in RSBF solution, the $\mathrm{pH}$ value attained was higher than for the KSBF one and magnesium phosphate was identified on the surface of $\mathrm{CA}, \mathrm{C}_{3} \mathrm{~A}$ and $\mathrm{C}_{12} \mathrm{~A}_{7}$ samples. Only for $\mathrm{CA}_{2}$, the optimal precipitation condition was attained in RSBF and a surface layer of the hydroxyapatite was detected. Based on its ability of stimulating hydroxyapatite deposition in $\mathrm{SBF}$ and other properties, $\mathrm{CA}_{2}$ can be eligible as the most suitable composition for biomedical purposes.
\end{abstract}

Keywords: dental cement, hydroxyapatite, simulated body fluid

\section{Introduction}

An ideal endodontic repairing biomaterial would adhere to the tooth structure, maintain suitable sealing, be insoluble in tissue fluids, be dimensionally stable, non-resorbable, radiopaque and show biocompatibility ${ }^{1}$.

Calcium aluminate-based cement (CAC) has already been studied for biomedical applications as endodontics ${ }^{2-6}$. This material presented good physical and mechanical properties ${ }^{7}$, biocompatibility ${ }^{8,9}$ and acted as a chemical and mechanical barrier against bacterial microleakage ${ }^{4}$. This sort of cement has also shown an absence of inflammatory reaction and it was biocompatible when tested on rat subcutaneous tissue ${ }^{2}$. In the presence of radiopacifier (bismuth oxide), it has also presented suitable radiopacity for all studied thicknesses, as recommended by ISO $6876^{10}$.

Another important desired property is bioactivity of endodontic materials, which has been defined as "the bond ability with the host bone tissue". In order to avoid costly experiments, various in vitro tests have been used to predict the in vivo bone bioactivity of bioceramics. One common method that has been used for testing in vitro bioactivity is to evaluate the apatite-formation ability of bioceramics in the simulated body fluids $(\mathrm{SBF})^{11,12}$. The examination of apatite formation on the surface of a material in SBF is useful

*e-mail: ivoneregina.oliveira@gmail.com for predicting the in vivo bone bioactivity of the material. Besides that it can reduce both, the number of animals used and the time length of the experiments, speeding up the development of new types of bioactive materials ${ }^{11}$. For a full evaluation of the in vitro bioactivity it is recommend the combination of SBF and cell experiment methods ${ }^{12,13}$. The ability to stimulate a cell response is very important and complements the in vitro apatite deposition data.

Recent studies involving the use of CAC are based on commercial products comprising a mixture of different crystalline phase $^{2-7}$. In vitro characterization of commercial CAC has been carried out in simulated body fluid solutions (SBF) prepared according to Kokubo's (KSBF) or Rigo's (RSBF) techniques. CAC presented ability of stimulating hydroxyapatite deposition in SBF, although the solution composition defines the sort of phases precipitated. The optimal condition for the calcium phosphate phase precipitation was attained in RSBF and a surface layer of stoichiometric hydroxyapatite could be detected by $\mathrm{XRD}^{14}$.

Improvements can be achieved by investigating the CAC production routes aiming at the proper balance between the phases and the control of impurities that may affect its performance for biomedical applications. The production of CAC phases was previously studied by the authors using $\mathrm{Al}_{2} \mathrm{O}_{3}-\mathrm{CaCO}_{3}$ or $\mathrm{Al}_{2} \mathrm{O}_{3}-\mathrm{CaO}$ as initial raw materials. The 
$\mathrm{Al}_{2} \mathrm{O}_{3}-\mathrm{CaO}$ route enabled the production of the target phases $\left(\mathrm{CA}, \mathrm{CA}_{2}, \mathrm{C}_{3} \mathrm{~A}\right.$ and $\mathrm{C}_{12} \mathrm{~A}_{7}$ ) with higher purity compared to the $\mathrm{Al}_{2} \mathrm{O}_{3}-\mathrm{CaCO}_{3}$ one in which $\mathrm{C}$ stands for $\mathrm{CaO}$ and $\mathrm{A}$ for $\mathrm{Al}_{2} \mathrm{O}_{3}{ }^{15}$.

Therefore, in this work in vitro characterization of calcium aluminate cement phases $\left(\mathrm{CA}, \mathrm{CA}_{2}, \mathrm{C}_{3} \mathrm{~A}\right.$ and $\left.\mathrm{C}_{12} \mathrm{~A}_{7}\right)$ was evaluated when in contact with simulated body fluid solutions. This can highlight the importance of each particular crystalline phase comprising the CAC containing product and provide better tools and insights in terms of designing its composition, application and performance.

\section{Experimental Procedures}

Calcium aluminate cement phases were previously synthesized by the $\mathrm{CaO}$ and $\mathrm{Al}_{2} \mathrm{O}_{3}$ calcination using electrical furnace at different temperatures and dwell time of one hour ${ }^{15}$.

The reactions involved to produce $\mathrm{CA}, \mathrm{CA}_{2}, \mathrm{C}_{3} \mathrm{~A}$ and $\mathrm{C}_{12} \mathrm{~A}_{7}$ phases as listed below:

$$
\begin{aligned}
& \mathrm{CaO}+\mathrm{Al}_{2} \mathrm{O}_{3} \rightarrow \mathrm{CaAl}_{2} \mathrm{O}_{4}(\mathrm{CA}) \\
& \mathrm{CaO}+2 \mathrm{Al}_{2} \mathrm{O}_{3} \rightarrow \mathrm{CaAl}_{4} \mathrm{O}_{7}\left(\mathrm{CA}_{2}\right) \\
& 3 \mathrm{CaO}+\mathrm{Al}_{2} \mathrm{O}_{3} \rightarrow \mathrm{Ca}_{3} \mathrm{Al}_{2} \mathrm{O}_{6}\left(\mathrm{C}_{3} \mathrm{~A}\right) \\
& 12 \mathrm{CaO}+7 \mathrm{Al}_{2} \mathrm{O}_{3} \rightarrow \mathrm{Ca}_{12} \mathrm{Al}_{14} \mathrm{O}_{33}\left(\mathrm{C}_{12} \mathrm{~A}_{7}\right)
\end{aligned}
$$

The raw material amounts used and the firing conditions were adjusted in order to produce different CAC phases as presented in Table 1. Following that, the resulting phases were dry ball milled for 17 hours using high alumina spheres with a 5:1 ratio (ball: powder) ${ }^{15}$.

Aqueous suspensions of CAC phases were prepared using a standard laboratory mixer under a $2000 \mathrm{rpm}$. Deionized water was added to these powders to obtain a homogeneous paste. The solid amount in the suspension is presented in Table 1. $\mathrm{C}_{3} \mathrm{~A}$ and $\mathrm{C}_{12} \mathrm{~A}_{7}$ suspensions were prepared with higher water content. The affinity of $\mathrm{CaO}$ with water and the high $\mathrm{CaO} / \mathrm{Al}_{2} \mathrm{O}_{3}$ ratio in these phases led to heat evolution when in contact with water. Thus, due to water evaporation, it was necessary to increase the content of water added.

The suspensions were used to prepare cylindrical samples (10mm diameter x $5 \mathrm{~mm}$ height). After shaping, the samples were kept at $37 \pm 1{ }^{\circ} \mathrm{C}$ in a climatic chamber under a saturate environment $(100 \%$ R. H.) for 24 hours. After that, the samples were withdrawn out of the molds and kept for 7 days at $37^{\circ} \mathrm{C}$ under the same environmental conditions described above. After finishing this step, they were placed into containers with $50 \mathrm{ml}$ of water or SBF solutions and kept at $37{ }^{\circ} \mathrm{C}(100 \%$ R. H. $)$. The $\mathrm{pH}$ of these solutions was measured at certain time intervals, using $\mathrm{pH}$ electrode connected to an automatic data recorder system.

The SBF solutions named KSBF and RSBF were prepared according to the procedure described in the literature ${ }^{11,16}$, as shown in Table 2.

The 7-day-set samples were also placed into containers with $47 \mathrm{~mL}$ of SBF solutions in order to keep a $0.1 \mathrm{~cm}^{-1}$ surface area-to-volume ratio and under stirring at $37^{\circ} \mathrm{C}$ with the help of a shaker. Afterwards the samples were gently rinsed with deionized water, followed by drying at room temperature according to the literature ${ }^{17}$. The surface of the samples was

Table 1. Processing conditions for the production of calcium aluminate cement phases based on $\mathrm{Al}_{2} \mathrm{O}_{3}-\mathrm{CaO}$ mixture and the respective

\begin{tabular}{|c|c|c|c|c|}
\hline Reagent & Order & SBF 1.5 Kokubo (KSBF) & Order & SBF 1.5 Rigo (RSBF) \\
\hline Water & $\# 0$ & $750 \mathrm{ml}$ & $\# 0$ & $400 \mathrm{ml}$ \\
\hline $\mathrm{NaCl}$ & $\# 1$ & $11.994 \mathrm{~g}$ & $\# 1$ & $11.992 \mathrm{~g}$ \\
\hline $\mathrm{NaHCO}_{3}$ & $\# 2$ & $0.525 \mathrm{~g}$ & $\# 4$ & $0.529 \mathrm{~g}$ \\
\hline $\mathrm{KCl}$ & $\# 3$ & $0.336 \mathrm{~g}$ & $\# 2$ & $0.335 \mathrm{~g}$ \\
\hline $\mathrm{K}_{2} \mathrm{HPO}_{4}$ & $\# 4$ & $0.288 \mathrm{~g}$ & $\# 3$ & $0.261 \mathrm{~g}$ \\
\hline $\mathrm{MgCl}_{2} \cdot 6 \mathrm{H}_{2} \mathrm{O}$ & $\# 5$ & $0.458 \mathrm{~g}$ & $\# 8$ & $0.458 \mathrm{~g}$ \\
\hline $\mathrm{HCl} 1 \mathrm{M}$ & \#6 & $60 \mathrm{ml}$ & & \\
\hline $\mathrm{HCl} 0.1 \mathrm{M}$ & & & $\# 6$ & $15 \mathrm{ml}$ \\
\hline $\mathrm{CaCl}_{2} \cdot 2 \mathrm{H}_{2} \mathrm{O}$ & $\# 7$ & $0.507 \mathrm{~g}$ & $\# 7$ & $0.551 \mathrm{~g}$ \\
\hline $\mathrm{Na}_{2} \mathrm{SO}_{4}$ & $\# 8$ & $0.107 \mathrm{~g}$ & $\# 5$ & $0.107 \mathrm{~g}$ \\
\hline$\left(\mathrm{CH}_{2} \mathrm{OH}\right)_{3} \mathrm{CNH}_{2}$ & $\# 9$ & $9.086 \mathrm{~g}$ & & \\
\hline $\begin{array}{c}\left(\mathrm{CH}_{2} \mathrm{OH}\right)_{3} \mathrm{CNH}_{2} \\
0.05 \mathrm{M}\end{array}$ & & & $\# 9$ & Suitable amount for adjusting $\mathrm{pH} 7.25$ \\
\hline $\mathrm{HCl} 1 \mathrm{M}$ & $\# 10$ & Suitable amount for adjusting $\mathrm{pH} 7.25$ & & \\
\hline $\mathrm{HCl} 0.1 \mathrm{M}$ & & & $\# 10$ & Suitable amount for adjusting $\mathrm{pH} 7.25$ \\
\hline
\end{tabular}
solid content in the suspension.

\begin{tabular}{cccc}
\hline CAC phase & Materials (wt\%) & Temperature $\left({ }^{\circ} \mathbf{C}\right)$ & $\begin{array}{c}\text { Solids in the } \\
\text { suspension (wt\%) }\end{array}$ \\
\hline $\mathrm{CA}$ & $\mathrm{Al}_{2} \mathrm{O}_{3}: \mathrm{CaO}(65: 35)$ & 1300 & 63 \\
$\mathrm{CA}_{2}$ & $\mathrm{Al}_{2} \mathrm{O}_{3}: \mathrm{CaO}(78: 22)$ & 1450 & 67 \\
$\mathrm{C}_{3} \mathrm{~A}$ & $\mathrm{Al}_{2} \mathrm{O}_{3}: \mathrm{CaO}(38: 62)$ & 1300 & 59 \\
$\mathrm{C}_{12} \mathrm{~A}_{7}$ & $\mathrm{Al}_{2} \mathrm{O}_{3}: \mathrm{CaO}(51: 49)$ & 1300 & 50 \\
\hline
\end{tabular}

Table 2. Reagent content for preparing the simulated body fluid (SBF) solutions (1L) according to the literature ${ }^{11,16}$. 
analyzed by scanning electron microscopy (SEM) and energy dispersive X-ray analysis (EDX) before and after treatment in SBF solutions. The samples before and after immersion in SBF were also analyzed by X-ray diffraction (XRD) using $\mathrm{CuK} \alpha$ radiation $(1.54439 \AA)$ in order to identify the phases formed on the sample surface.

\section{Results and Discussion}

\section{1. $\mathrm{pH}$ tests}

CAC phases, mainly $\mathrm{CA}, \mathrm{C}_{3} \mathrm{~A}$ and $\mathrm{C}_{12} \mathrm{~A}_{7}$, increased the water $\mathrm{pH}$ (Figure 1A). In simulated body fluid, higher $\mathrm{pH}$ values were attained in RSBF. $\mathrm{pH}$ measurements with the time for SBF solutions in contact with previously set CA, $\mathrm{CA}_{2}, \mathrm{C}_{3} \mathrm{~A}$ or $\mathrm{C}_{12} \mathrm{~A}_{7}$ samples showed values in the range 7.5-8.5 as soon as they were placed in KSBF (Figure 1B). Conversely, $\mathrm{CA}, \mathrm{C}_{3} \mathrm{~A}$ and $\mathrm{C}_{12} \mathrm{~A}_{7}$ phases presented higher $\mathrm{pH}$ in RSBF, reaching values close to $9.5-10$ in the first couple of days, whereas $\mathrm{pH}$ of approximately 9 was attained for $\mathrm{CA}_{2}$ one (Figure 1C).

\subsection{SBF tests}

The EDX spectra of the surface of the samples before immersion in SBF confirmed presence of the main chemical constituents of hydrated $\mathrm{CA}$ and $\mathrm{CA}_{2}$ phases (aluminum $>$ oxygen $>$ calcium) (Figure $2 \mathrm{~A}$ and $\mathrm{C}$ ) and those for the $\mathrm{C}_{3} \mathrm{~A}$ and $\mathrm{C}_{12} \mathrm{~A}_{7}$ ones (calcium $>$ aluminum $>$ oxygen), as shown in Figures $3 \mathrm{~A}$ and $\mathrm{C}$.

EDX spectra and SEM analysis of set samples after immersion for 7 days in SBF solutions prepared according to Rigo's are shown in Figures 3 and 4, respectively. The presence of phosphorus was identified mostly for $\mathrm{CA}_{2}$ indicating the formation of a calcium phosphate phase on the sample surface. For the other phases was identified the presence of $\mathrm{Mg}^{2+}$ ions on their surfaces (Figures 2 and 3).

XRD analysis of set samples before and after immersion for 7 days in SBF solutions are shown in Figures 5-8. Calcium phosphate phases were not identified on the surface of CAC phases after treatment with KSBF. On the other hand, magnesium phosphate $\left[\mathrm{Mg}_{3}\left(\mathrm{PO}_{4}\right)_{2} \cdot 22 \mathrm{H}_{2} \mathrm{O}\right]$ was detected on the surface of $\mathrm{CA}, \mathrm{C}_{3} \mathrm{~A}$ and $\mathrm{C}_{12} \mathrm{~A}_{7}$ after immersion in RSBF. Hydroxyapatite $\left[\mathrm{Ca}_{5}\left(\mathrm{PO}_{4}\right)_{3} \mathrm{OH}\right]$ was only detected on the surface of $\mathrm{CA}_{2}$ after immersion in RSBF.

The hydration products of commercial CAC (usually comprising a mixture of $\mathrm{CA}, \mathrm{CA}_{2}$ and $\mathrm{C}_{12} \mathrm{~A}_{7}$ ) in water are calcium aluminate hydrates and aluminum hydroxide. At temperatures above $35{ }^{\circ} \mathrm{C}, \mathrm{C}_{3} \mathrm{AH}_{6}\left(3 \mathrm{CaO} \cdot \mathrm{Al}_{2} \mathrm{O}_{3} \cdot 6 \mathrm{H}_{2} \mathrm{O}\right.$ or $\left.\mathrm{Ca}_{3}\left[\mathrm{Al}(\mathrm{OH})_{4}\right]_{2}(\mathrm{OH})_{4}\right)$ is the main hydrated phase ${ }^{18}$ :

$3\left(\mathrm{CaO} \cdot \mathrm{Al}_{2} \mathrm{O}_{3}\right)+12 \mathrm{H}_{2} \mathrm{O} \rightarrow \mathrm{Ca}_{3}\left[\mathrm{Al}(\mathrm{OH})_{4}\right]_{2}(\mathrm{OH})_{4}+4 \mathrm{Al}(\mathrm{OH})_{3}$

However, the calcium aluminate hydrate formed also depends on the $\mathrm{CaO}$ content in the anhydrous phase ${ }^{18}$. For $\mathrm{C}_{3} \mathrm{~A}$ and $\mathrm{C}_{12} \mathrm{~A}_{7}$ as precursors, $\mathrm{C}_{3} \mathrm{AH}_{6}$ was the major one (Figures 7 and 8A). On the other hand, for CA and mainly $\mathrm{CA}_{2}$, the precipitation of $\mathrm{C}_{2} \mathrm{AH}_{8}\left(2 \mathrm{CaO} \cdot \mathrm{Al}_{2} \mathrm{O}_{3} \cdot 8 \mathrm{H}_{2} \mathrm{O}\right)$ and $\mathrm{CAH}_{10}\left(\mathrm{CaO} \cdot \mathrm{Al}_{2} \mathrm{O}_{3} \cdot 10 \mathrm{H}_{2} \mathrm{O}\right)$ was identified (Figures 5 and $\left.6 \mathrm{~A}\right)$. After hardening and in contact with $\mathrm{SBF}$ solution, the hydrates are the main soluble phase, as $\mathrm{Al}(\mathrm{OH})_{3}$ is insoluble in water. The $\mathrm{Ca}^{2+}$ ions from the hydrates dissolution react

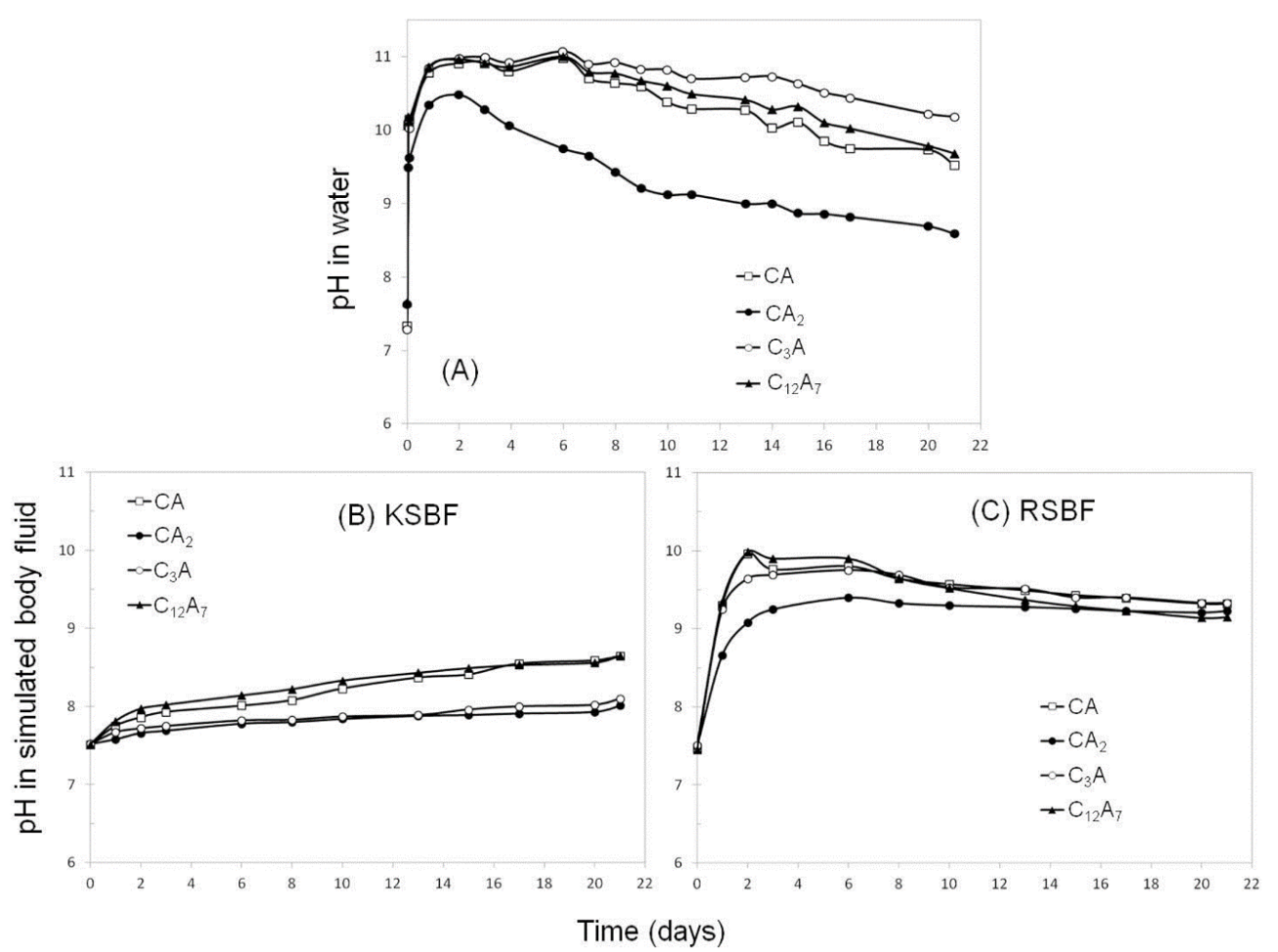

Figure 1. $\mathrm{pH}$ as a function of the time for (A) water, (B) SBF (simulated body fluid) Kokubo and (C) SBF Rigo solutions in contact with $\mathrm{CA}, \mathrm{CA}_{2}, \mathrm{C}_{3} \mathrm{~A}$ and $\mathrm{C}_{12} \mathrm{~A}_{7}$ sample phases. 
with $\mathrm{HCO}_{3}{ }^{-}$in the solution resulting in calcium carbonate, as identified by XRD (Figures 5-8) according to reactions:

$$
\begin{aligned}
& \mathrm{CO}_{2}+\mathrm{H}_{2} \mathrm{O} \leftrightarrow \mathrm{H}^{+}+\mathrm{HCO}_{3}^{-} \\
& \mathrm{Ca}^{2+}+\mathrm{HCO}_{3}^{-} \leftrightarrow \mathrm{CaCO}_{3}+\mathrm{H}^{+}
\end{aligned}
$$

The $\mathrm{Ca}^{2+}$ and $\mathrm{OH}^{-}$ions leached out from the samples, can also react with phosphorus ions of the solution resulting in hydroxyapatite crystals on the material's surface:

$$
5 \mathrm{Ca}^{2+}+3\left(\mathrm{PO}_{4}\right)^{3-}+(\mathrm{OH})^{-1} \rightarrow \mathrm{Ca}_{5}\left(\mathrm{PO}_{4}\right)_{3}(\mathrm{OH})
$$

According to the literature, the bioactivity has been attributed to the ability to generate hydroxyapatite in the presence of phosphate-containing solution ${ }^{12,19}$. The resulting surface hydroxyapatite layer is similar in structure to the mineral components of bone and teeth ${ }^{20}$. Materials with an apatite surface layer develop a chemical bond and biological integration with the bone ${ }^{21}$. The in vitro precipitation of hydroxyapatite on the surface of a material in SBF indicates
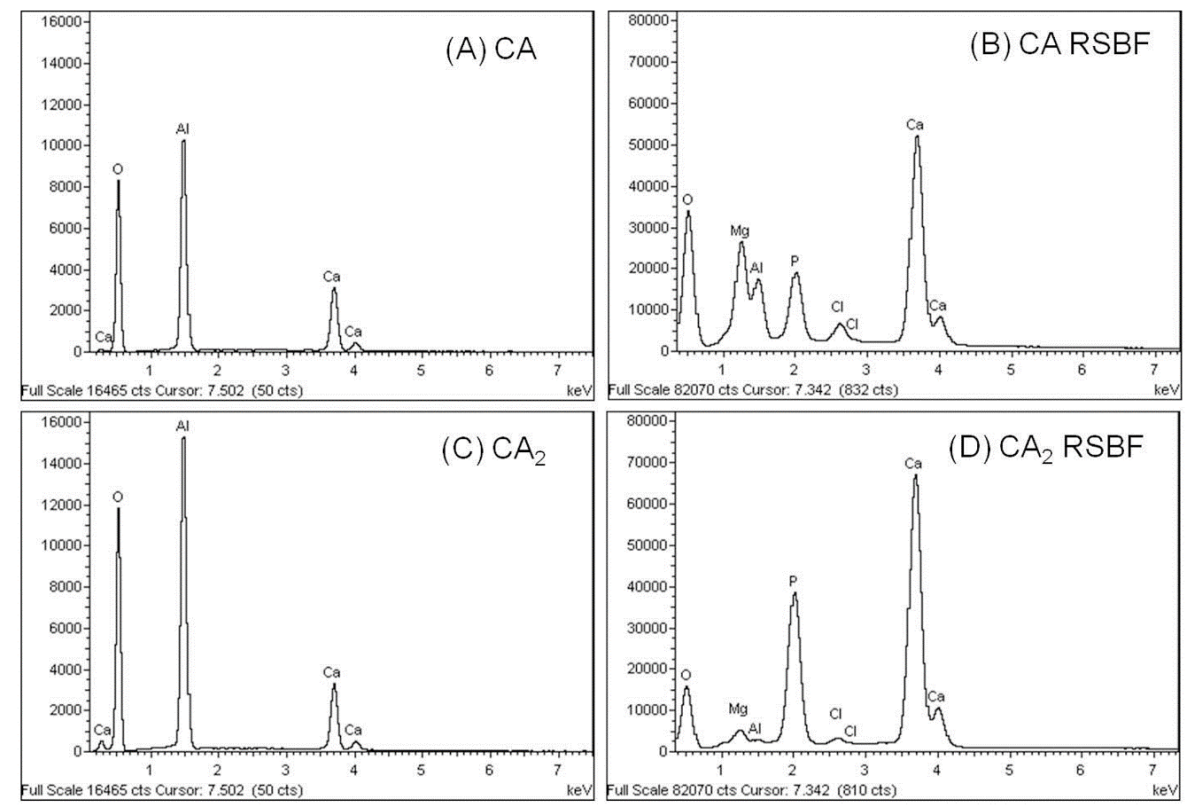

Figure 2. EDX spectra of the surface of the phases before immersion in SBF: (A) CA, (C) $\mathrm{CA}_{2}$ and after 7 days in SBF Rigo: (B) CA RSBF, (D) $\mathrm{CA}_{2} \mathrm{RSBF}$.

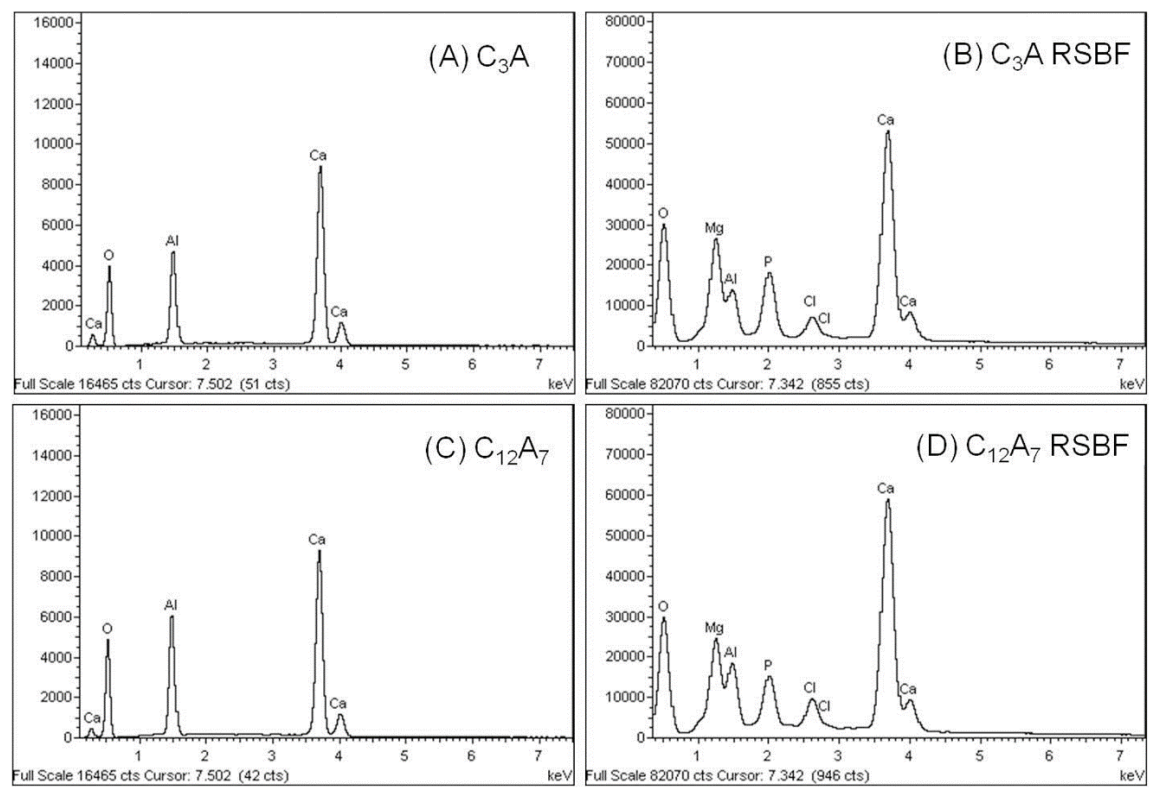

Figure 3. EDX spectra of the surface of the phases before immersion in SBF: (A) $C_{3} A,(C) C_{12} A_{7}$ and after 7 days in SBF Rigo: (B) $C_{3} A$ RSBF, (D) $\mathrm{C}_{12} \mathrm{~A}_{7} \mathrm{RSBF}$. 
its bioactivity ${ }^{17}$. However, there is a misunderstanding regarding the concept of bioactivity. Bohner and Lemaitre published a review which questioned whether currently there was enough scientific evidence to support the assumptions around the use of the SBF method ${ }^{13}$. Thus it is recommend the combination of SBF and cell experiment techniques to evaluate the in vitro bioactivity ${ }^{12}$.

Solutions of simulated body fluid used in this work contained similar inorganic ion concentrations to those in human extracellular fluid (human plasma) in order to reproduce the in vitro formation of apatite on bioactive material. SBF is a metastable solution containing calcium and phosphate ions already saturated with apatite ${ }^{11,16}$. The increase in both $\mathrm{pH}$ and $\mathrm{Ca}^{2+}$ concentration result in the supersaturation of SBF solution leading to the precipitation of hydroxyapatite ${ }^{20}$.

However, the $\mathrm{OH}^{-}$ions released are not enough to result in the $\mathrm{pH}$ increase and to induce the KSBF supersaturation as its value was kept close to 7.5-8.5 for the whole experiment
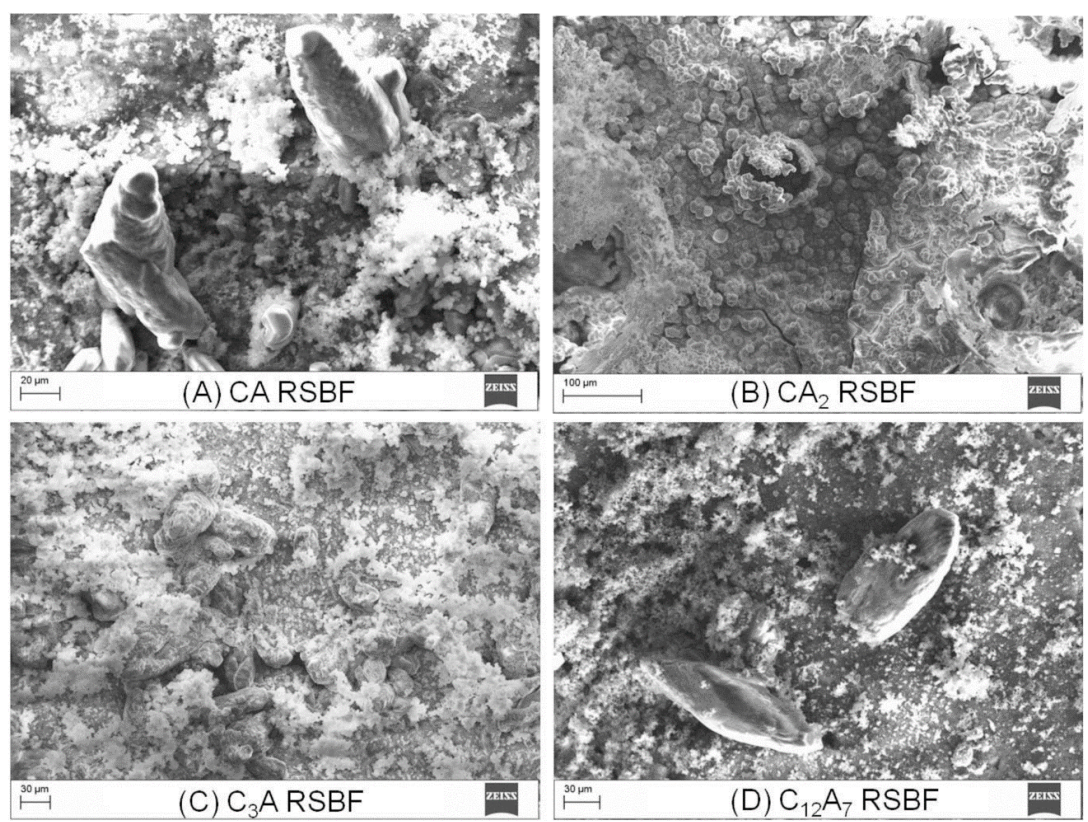

Figure 4. Electron micrographs depicting the surface of the phases (A) $C A,(C) C_{3} A$, (B) $C_{2}$, and (D) $C_{12} A_{7}$ after 7 days in SBF Rigo
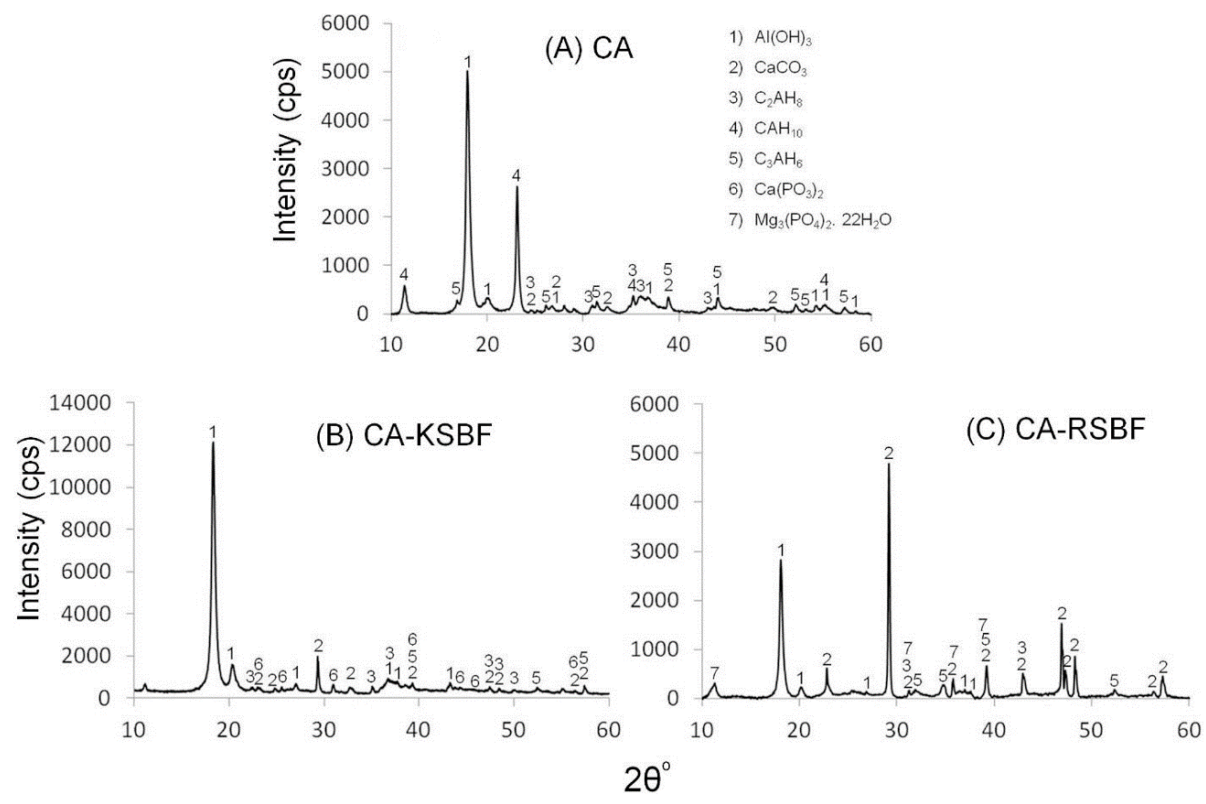

Figure 5. XRD patterns of CA (A) before immersion in SBF; (B) after 7 days in KSBF and (C) after 7 days in RSBF. 
time range (Figure 1B). This explains why the formation of a calcium phosphate phase on the sample surface was not detected (Figures 5-8B).

Conversely, the formation of phosphate phases on the CAC phases sample surface was favored in RSBF (Figures 5-8). The main difference between the solutions is the buffering content. According to Rigo et al. ${ }^{16}$, the buffer Tris, $\left(\mathrm{CH}_{2} \mathrm{OH}\right)_{3} \mathrm{CNH}_{2}$, is added only at the right amount to adjust the $\mathrm{pH}$ to 7.25 , whereas in KSBF, a higher content of this compound is used. This difference could most likely explain the $\mathrm{pH}$ increase detected for the RSBF, resulting in the SBF solution supersaturation and consequently the formation of phosphate phases on the sample surface.

The hydrates formed from $\mathrm{CA}$ and mainly $\mathrm{C}_{3} \mathrm{~A}$ and $\mathrm{C}_{12} \mathrm{~A}_{7}$ samples are richer in $\mathrm{CaO}$, resulting in more $\mathrm{OH}^{-}$ions leached out from the samples leading to $\mathrm{pH}$ values above 9.5 in $\mathrm{RSBF}$, whereas for the $\mathrm{CA}_{2}$ ones (less rich in $\mathrm{CaO})$ result in lower $\mathrm{pH}(\sim 9.0)$.

Therefore, for the $\mathrm{CA}, \mathrm{C}_{3} \mathrm{~A}$ and $\mathrm{C}_{12} \mathrm{~A}_{7}$ phases in the presence of RSBF the lower content of buffer allowed the faster $\mathrm{pH}$ increase (close to 9.5-10). This can be

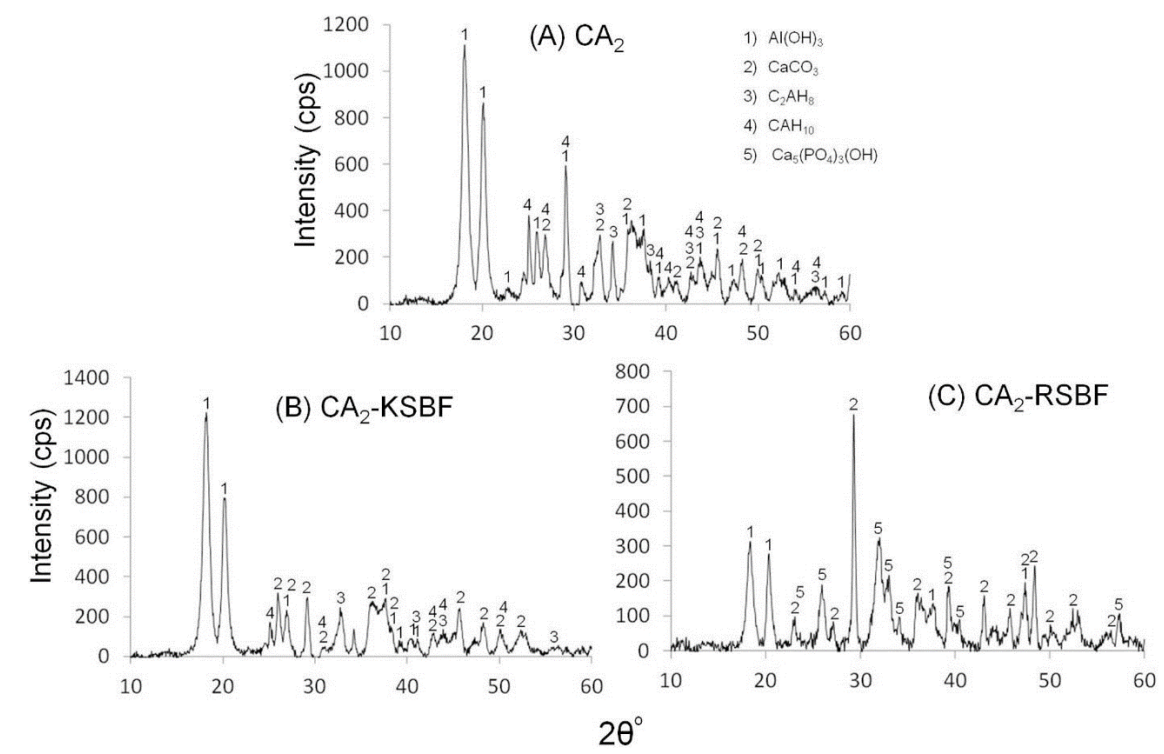

Figure 6. XRD patterns of $\mathrm{CA}_{2}$ (A) before immersion in SBF; (B) after 7 days in $\mathrm{KSBF}$ and (C) after 7 days in RSBF.
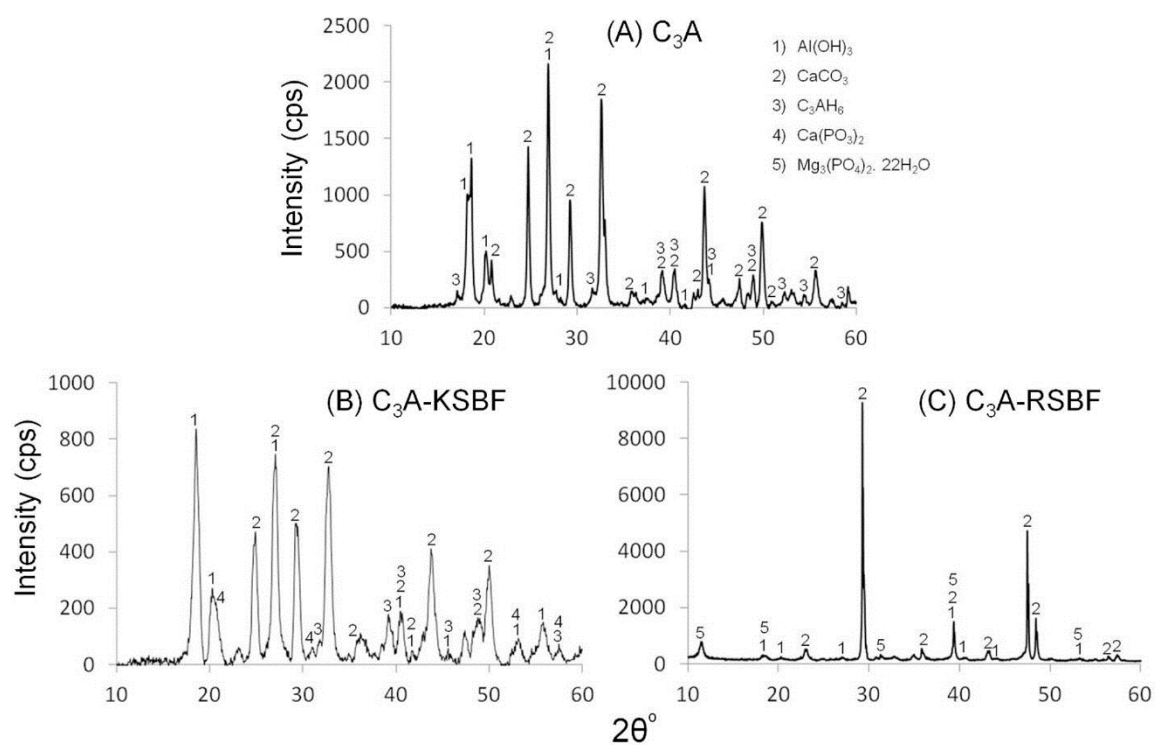

Figure 7. XRD patterns of $\mathrm{C}_{3} \mathrm{~A}(\mathrm{~A})$ before immersion in SBF; (B) after 7 days in KSBF and (C) after 7 days in RSBF. 

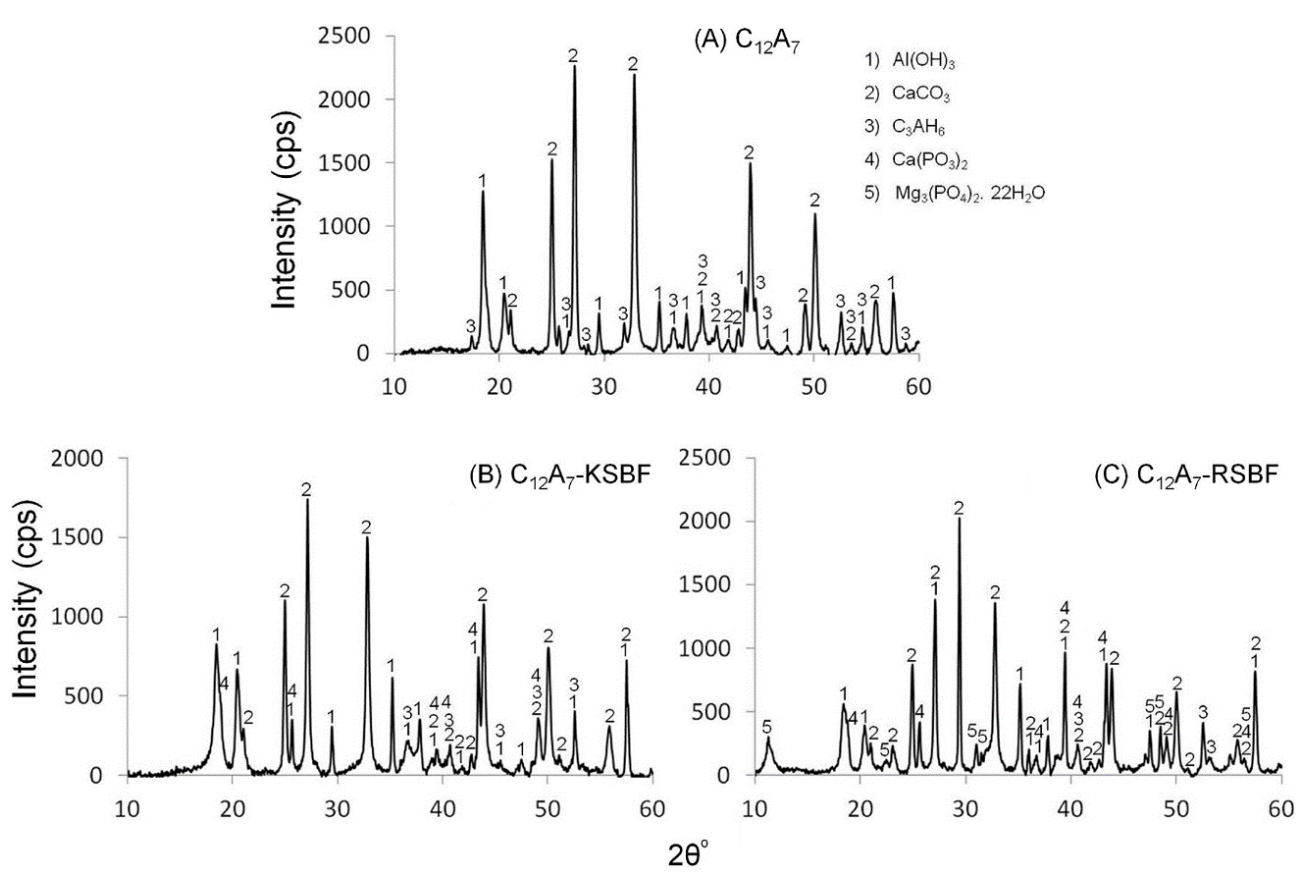

Figure 8. XRD patterns of $\mathrm{C}_{12} \mathrm{~A}_{7}$ (A) before immersion in SBF; (B) after 7 days in KSBF and (C) after 7 days in RSBF.

confirmed by the presence of $\mathrm{Mg}^{2+}$ ions on the surfaces of samples (Figures 2 and 3 ) which were precipitated from the SBF solution. It has been reported in the literature that magnesium phosphate precipitation is more noticeable at higher $\mathrm{pH}$ and inhibits the precipitation of calcium phosphate ${ }^{22,23}$. Thus, calcium carbonate precipitate can be observed by SEM on the $\mathrm{CA}, \mathrm{C}_{3} \mathrm{~A}$ and $\mathrm{C}_{12} \mathrm{~A}_{7}$ surfaces (Figure 4).

XRD results also showed that the calcium phosphate was not precipitated on the $\mathrm{CA}, \mathrm{C}_{3} \mathrm{~A}$ and $\mathrm{C}_{12} \mathrm{~A}_{7}$ sample surface when in RSBF and that the magnesium ion detected by EDX was most likely precipitated as magnesium phosphate (Figures 5, 7 and 8C).

On the other hand, on the surface of the $\mathrm{CA}_{2}$ sample after immersion in RSBF, stoichiometric hydroxyapatite $\left[\mathrm{Ca}_{5}\left(\mathrm{PO}_{4}\right)_{3} \mathrm{OH}\right]$ was detected (Figure $6 \mathrm{C}$ ) as the $\mathrm{pH}$ condition (approximately 9) did not favor the magnesium phosphate precipitation. Hydroxyapatite is the natural biomineral representing 30 to 70 mass $\%$ of bones and teeth ${ }^{24}$.

Besides providing better results for the ability of stimulating hydroxyapatite deposition, Pompeu et al..$^{25}$ also indicated the $\mathrm{CA}_{2}$ phase as the most suitable for applications in endodontics when compared to $\mathrm{CA}, \mathrm{C}_{3} \mathrm{~A}$ and $\mathrm{C}_{12} \mathrm{~A}_{7}$ ones. $\mathrm{CA}_{2}$ presented a lower temperature increase during hydration process, which is essential to avoid necrosis of the bone tissue around the implant region ${ }^{26}$. $\mathrm{CA}_{2}$ also showed ability to induce an antibacterial environment and interaction with ions in solution simulated body fluid and showed no dissolution in water or SBF.

However, $\mathrm{CA}_{2}$ presented the longest setting time due to the formation of a more soluble hydrate $\left(\mathrm{CAH}_{10}\right)$ when compared to a less soluble one, such as $\mathrm{C}_{3} \mathrm{AH}_{6}$. Therefore, to attain a suitable setting time, the addition of accelerating additives is required. The use of cements with a lower setting time should decrease the need of constant professional procedures during the treatment. Besides that, when used as a root-end or root-canal filling material the fast set should also reduce the risk of contamination and dislodgement after placement ${ }^{27}$.

\section{Conclusions}

Calcium phosphate phases were not detected on the surface of CAC samples phases after immersion in KSBF as the release of $\mathrm{OH}^{-}$ions was not sufficient to increase the $\mathrm{pH}$ and to enhance the KSBF's supersaturation.

Conversely, in RSBF the lower content of buffer allowed a faster $\mathrm{pH}$ increase, resulting in the precipitation of magnesium phosphate on CAC sample surfaces. Only for the $\mathrm{CA}_{2}$ samples, the $\mathrm{pH}$ attained favored the calcium phosphate phase precipitation and a surface layer of the stoichiometric hydroxyapatite could be detected by XRD.

Based on its ability of stimulating hydroxyapatite deposition in SBF and other properties, among all phases of calcium aluminate endodontic cement evaluated, the $\mathrm{CA}_{2}$ one containing accelerating additives can be eligible as the most suitable composition for biomedical purposes. However, in order to evaluate its in vitro bioactivity it is still necessary combination of SBF tests and cell experiments methods.

\section{Acknowledgements}

The authors are grateful to grant \#2009/17451-0 and \#2013/22502-8, São Paulo Research Foundation and National Council for Scientific and Technological Development - Brazil for providing financial support for this research. 


\section{References}

1. Roberts HW, Toth JM, Berzins DW and Charlton DG. Mineral trioxide aggregate material use in endodontic treatment: a review of the literature. Dental Materials. 2008; 24(2):149-164. http:// dx.doi.org/10.1016/j.dental.2007.04.007. PMid:17586038

2. Aguilar FG, Roberti Garcia LF and Panzeri Pires-de-Souza FC. Biocompatibility of new calcium aluminate cement (EndoBinder). Journal of Endodontics. 2012; 38(3):367-371. http://dx.doi.org/10.1016/j.joen.2011.11.002. PMid:22341076

3. Engqvist H, Schultz-Walz JE, Loof J, Botton GA, Mayer D, Phaneuf MW, et al. Chemical and biological integration of a mouldable bioactive ceramic material capable of forming apatite in vivo in teeth. Biomaterials. 2004; 25(14):2781-2787. http:// dx.doi.org/10.1016/j.biomaterials.2003.09.053. PMid:14962556

4. Jacobovitz M, Vianna ME, Pandolfelli VC, Oliveira IR, Rossetto HL and Gomes BPFA. Root canal filling with cements based on mineral aggregates: an in vitro analysis of bacterial microleakage. Oral Surgery, Oral Medicine, Oral Pathology, Oral Radiology, and Endodontics. 2009; 108(1):140-144. http:// dx.doi.org/10.1016/j.tripleo.2009.03.013. PMid:19540451

5. Loof J, Engqvist H, Ahnfelt NO, Lindqvist $\mathrm{K}$ and Hermansson L. Mechanical properties of a permanent dental restorative material based on calcium aluminate. Journal of Materials Science. Materials in Medicine. 2003; 14(12):1033-1037. http://dx.doi.org/10.1023/B:JMSM.0000003999.52349.0d. PMid:15348495

6. Pandolfelli VC, Oliveira IR, Rossetto HL and Jacobovitz M. Aluminous cement-based composition for application in endodontics and cementitious product obtained thereof 2009. WO/2009/067774. 2009.

7. Oliveira IR, Pandolfelli VC and Jacobovitz M. Chemical, physical and mechanical properties of a novel calcium aluminate endodontic cement. International Endodontic Journal. 2010; 43(12):10691076. http://dx.doi.org/10.1111/j.1365-2591.2010.01770.x. PMid:20726916

8. Castro-Raucci LM, Oliveira IR, Teixeira LN, Rosa AL, Oliveira PT and Jacobovitz M. Effects of a novel calcium aluminate cement on the early events of the progression of osteogenic cell cultures. Brazilian Dental Journal. 2011; 22(2):99-104. http:// dx.doi.org/10.1590/S0103-64402011000200002. PMid:21537581

9. Silva EJNL, Herrera DR, Almeida JFA, Ferraz CCR, Gomes BPFA and Zaia AA. Evaluation of cytotoxicity and up-regulation of gelatinases in fibroblast cells by three root repair materials. International Endodontic Journal. 2012; 45(9):815-820. http:// dx.doi.org/10.1111/j.1365-2591.2012.02038.x. PMid:22452531

10. Aguilar FG, Garcia LF, Rossetto HL, Pardini LC and Piresde-Souza FC. Radiopacity evaluation of calcium aluminate cement containing different radiopacifying agents. Journal of Endodontics. 2011; 37(1):67-71. http://dx.doi.org/10.1016/j. joen.2010.10.001. PMid:21146080

11. Kokubo T and Takadama H. How useful is SBF in predicting in vivo bone bioactivity? Biomaterials. 2006; 27(15):29072915. http://dx.doi.org/10.1016/j.biomaterials.2006.01.017. PMid:16448693

12. Wu C and Xiao Y. Evaluation of the in vitro bioactivity of bioceramics. Bone and Tissue Regeneration Insights. 2009; 2:25-29.

13. Bohner M and Lemaitre J. Can bioactivity be tested in vitro with SBF solution? Biomaterials. 2009; 30(12):2175-2179. http:// dx.doi.org/10.1016/j.biomaterials.2009.01.008. PMid:19176246

14. Oliveira IR, Andrade TL, Jacobovitz M and Pandolfelli VC. Bioactivity of calcium aluminate endodontic cement. Journal of
Endodontics. 2013; 39(6):774-778. http://dx.doi.org/10.1016/j. joen.2013.01.013. PMid:23683278

15. Andrade TL, Santos GL, Pandolfelli VC and Oliveira IR. Synthesis optimization of calcium aluminate cement phases for biomedical applications [in Portuguese]. Cerâmica. 2014; 60(353):88-95. http://dx.doi.org/10.1590/S0366-69132014000100013.

16. Rigo ECS, Boschi AO, Yoshimoto M, Allegrini S Jr, Konig $\mathrm{B} \mathrm{Jr}$ and Carbonari MJ. Evaluation in vitro and in vivo of biomimetic hydroxyapatite coated on titanium dental implants. Materials Science and Engineering C. 2004; 24(5):647-651. http://dx.doi.org/10.1016/j.msec.2004.08.044.

17. Wang X, Sun $\mathrm{H}$ and Chang J. Characterization of $\mathrm{Ca} 3 \mathrm{SiO} 5 / \mathrm{CaCl} 2$ composite cement for dental application. Dental Materials. 2008; 24(1):74-82. http://dx.doi.org/10.1016/j.dental.2007.02.006. PMid: 17391748

18. Garcia JR, Oliveira IR and Pandolfelli VC. Hydration process and the mechanisms of retarding and accelerating the setting time of calcium aluminate cement. [in Portuguese]. Cerâmica. 2007; 53:42-56.

19. Tay FR, Pashley DH, Rueggeberg FA, Loushine RJ and Weller RN. Calcium phosphate phase transformation produced by the interaction of the portland cement component of white mineral trioxide aggregate with a phosphate-containing fluid. Journal of Endodontics. 2007; 33(11):1347-1351. http://dx.doi. org/10.1016/j.joen.2007.07.008. PMid:17963961

20. Coleman NJ, Nicholson JW and Awosanya K. A preliminary investigation of the in vitro bioactivity of white portland cement. Cement and Concrete Research. 2007; 37(11):1518-1523. http:// dx.doi.org/10.1016/j.cemconres.2007.08.008.

21. Sarkar NK, Caicedo R, Ritwik P, Moiseyeva R and Kawashima I. Physicochemical basis of the biologic properties of mineral trioxide aggregate. Journal of Endodontics. 2005; 31(2):97100. http://dx.doi.org/10.1097/01.DON.0000133155.04468.41. PMid:15671817

22. Barrére F, Layrolle P, van Blitterswijk CA and de Groot K. Biomimetic calcium phosphate coatings on Ti6AI4V: a crystal growth study of octacalcium phosphate and inhibition by $\mathrm{Mg} 2+$ and HCO3-. Bone. 1999;25(2, Suppl):107S-111S. http://dx.doi. org/10.1016/S8756-3282(99)00145-3. PMid:10458288

23. Martens CS and Harriss RC. Inhibition of apatite precipitation in the marine environment by magnesium ions. Geochimica et Cosmochimica Acta. 1970; 34(5):621-625. http://dx.doi. org/10.1016/0016-7037(70)90020-7.

24. Loof J. Calcium-aluminate as biomaterial: synthesis, design and evaluation. [Thesis]. Uppsala: Faculty of Science and Technology; 2008.

25. Pompeu LLMF, Santos GL, Pandolfelli VC and Oliveira IR. Calcium aluminates potential for endodontics and orthopedics application [in Portuguese]. Cerâmica. 2013; 59:216-224. http:// dx.doi.org/10.1590/S0366-69132013000200004.

26. Oréfice RL, Pereira MM and Mansur HS. Biomaterials: fundamentals and applications. Rio de Janeiro: Medical Culture; 2006. $538 \mathrm{p}$.

27. Camilleri J. The physical properties of accelerated Portland cement for endodontic use. International Endodontic Journal. 2008; 41(2):151-157. PMid:17931386. 